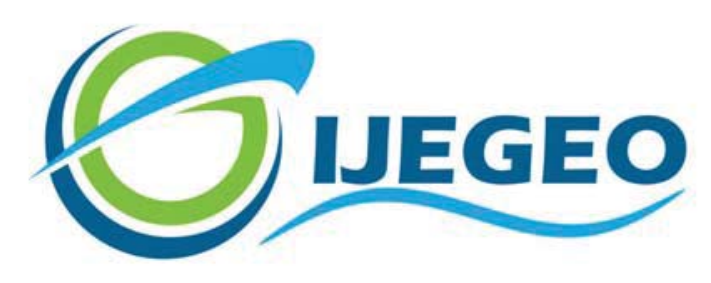

International Journal of Environment and Geoinformatics (IJEGEO) is an international, multidisciplinary, peer reviewed, open access journal.

\title{
Determination of Mucilage in The Sea of Marmara Using Remote Sensing Techniques with Google Earth Engine
}

\section{Uğur ACAR., Osman Salih YILMAZ, Meltem ÇELEN, Ali Murat ATEŞ, Fatih GÜLGEN, Füsun BALIK ŞANLI}

\author{
Chief in Editor \\ Prof. Dr. Cem Gazioğlu \\ Co-Editors \\ Prof. Dr. Dursun Zafer Şeker, Prof. Dr. Şinasi Kaya, \\ Prof. Dr. Ayşegül Tanık and Assist. Prof. Dr. Volkan Demir
}

Editorial Committee (December 2021)

\begin{abstract}
Assoc. Prof. Dr. Abdullah Aksu (TR), Assit. Prof. Dr. Uğur Algancı (TR), Prof. Dr. Bedri Alpar (TR), Assoc. Prof. Dr. Aslı Aslan (US), Prof. Dr. Levent Bat (TR), Prof. Dr. Paul Bates (UK), İrşad Bayırhan (TR), Prof. Dr. Bülent Bayram (TR), Prof. Dr. Luis M. Botana (ES), Prof. Dr. Nuray Çağlar (TR), Prof. Dr. Sukanta Dash (IN), Dr. Soofia T. Elias (UK), Prof. Dr. A. Evren Erginal (TR), Assoc. Prof. Dr. Cüneyt Erenoğlu (TR), Dr. Dieter Fritsch (DE), Prof. Dr. Çiğdem Göksel (TR), Prof.Dr. Lena Halounova (CZ), Prof. Dr. Manik Kalubarme (IN), Dr. Hakan Kaya (TR), Assist. Prof. Dr. Serkan Kükrer (TR), Assoc. Prof. Dr. Maged Marghany (MY), Prof. Dr. Michael Meadows (ZA), Prof. Dr. Nebiye Musaoğlu (TR), Prof. Dr. Masafumi Nakagawa (JP), Prof. Dr. Hasan Özdemir (TR), Prof. Dr. Chryssy Potsiou (GR), Prof. Dr. Erol Sarı (TR), Prof. Dr. Maria Paradiso (IT), Prof. Dr. Petros Patias (GR), Prof. Dr. Elif Sertel (TR), Prof. Dr. Nüket Sivri (TR), Prof. Dr. Füsun Balık Şanlı (TR), Prof. Dr. Uğur Şanlı (TR), Duygu Ülker (TR), Prof. Dr. Seyfettin Taş (TR), Assoc. Prof. Dr. Ömer Suat Taşkın (TR), Assist. Prof. Dr. Tuba Ünsal (TR), Dr. Manousos Valyrakis (UK), Dr. İnese Varna (LV), Dr. Petra Visser (NL), Prof. Dr. Selma Ünlü (TR), Assoc. Prof. Dr. Oral Yağcı (TR), Prof. Dr. Murat Yakar (TR), Assoc. Prof. Dr. İ. Noyan Yılmaz (AU); Assit. Prof. Dr. Sibel Zeki (TR)
\end{abstract}




\title{
Determination of Mucilage in The Sea of Marmara Using Remote Sensing Techniques with Google Earth Engine
}

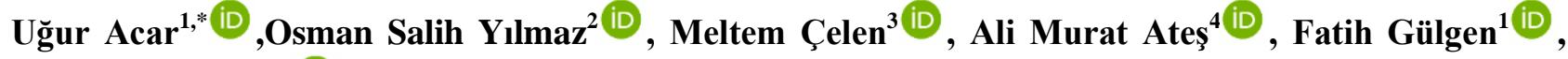 \\ Füsun Balık Şanlı 1 iD
}

${ }^{1}$ Yildiz Technical University, Faculty of Civil Engineering, Geomatic Engineering Department, Istanbul, TR

${ }^{2}$ Manisa Celal Bayar University, Demirci Vocational School, Department of Geographic Information System, Manisa, TR

${ }^{3}$ Gebze Technical University, Institute of Earth and Marine Sciences, Kocaeli, TR

${ }^{4}$ Manisa Celal Bayar University, Faculty of Education, Computer and Instructional Technologies Department, Manisa, TR

* Corresponding author: U.Acar

E-mail: uacar@yildiz.edu.tr

Received: 13.06 .2021

Accepted: 25.06 .2021

How to cite: Acar et al., (2021). Determination of Mucilage in The Sea of Marmara Using Remote Sensing Techniques with Google Earth Engine. International Journal of Environment and Geoinformatics (IJEGEO), 8(4):423-434. DOI: 10.30897/ijegeo.957284

\begin{abstract}
In this study, a methodology has been developed for the detection of mucilage with the help of remote sensing (UA) techniques by considering the current mucilage formation in the Sea of Marmara. For this purpose, mucilage formation from10.03.2021 to 06.06.2021 was determined by classification of Sentinel-2 (MSI) satellite images using Random Forest (RF) algorithm on Google Earth Engine (GEE) platform. Normalized Difference Vegetation Index (NDVI), Normalized Difference Water Index (NDWI), the Modified Normalized Difference Water Index (MNDWI) and the Automated Water Extraction Index (AWEI) indexes were used for classification. In the classification study, 5 different date ranges were determined by considering the availability of satellite images and cloud ratio. In the first date range (10.03.2021-30.03.2021), the first mucilage image was detected in the Dardanelles Strait. In the following dates, the spread of mucilage towards the Gulf of Izmit and the Gulf of Gemlik in addition to the Dardanelles was determined. Finally, in the images dated between 17.05.2021-06.06.2021, it was seen that the density of mucilage increased in the Dardanelles Strait, Izmit Gulf, Gemlik Gulf, Erdek Kapıdağ Peninsula and the north of the Marmara Island. The area covered by mucilage as of the last date range was calculated as 12,741.94 ha, and this value shows that $1.07 \%$ of the Sea of Marmara is covered with mucilage. With this developed methodology, it has been seen that mucilage formation can be detected quickly within minutes and with high accuracy from satellite images anywhere in the world.
\end{abstract}

Keywords: Marmara Sea, Mucilage, Google Earth Engine, Remote Sensing

\section{Introduction}

The Sea of Marmara is an important and strategic inland sea that connects the Asian and European continents. It also connects the Black Sea to the Aegean and Mediterranean Seas via the Istanbul and Dardanelles Straits. The Sea of Marmara is one of the most important seas of Turkey in terms of economy, logistics and strategy, as it has a coast to the mega city of Istanbul. In the Sea of Marmara, an East-West direction current is observed instead of circular movements arising from the Earth's rotation (koriolis) power. This current carries the Black Sea waters, whose salinity varies between $1.8 \%$ and $2.0 \%$, towards the Mediterranean. In the Sea of Marmara, an undercurrent is observed in the West-East direction due to the change in salt rates. This undercurrent causes the formation of two different water layers in the Sea of Marmara (Besiktepe et al., 1994; Artüz, 2002).

These currents observed in the Sea of Marmara, the increase in pollution in the sea due to the continuous development of the surrounding provinces and the rise in sea temperature have led to an increase in the biological activity in the Sea of Marmara in recent years. Plankton, which is formed as a result of this biological activity, increases excessively due to the decrease in the number and species of fish in the sea and causes the formation of mucilage on the sea surface (Balkıs-Ozdelice et al., 2021; Savun-Hekimoğlu and Gazioğlu, 2021). Mucilage is also known very broadly as sea snow, clumped mass, foam accumulation, flocculation and mucus agglomeration (Özalp, 2021). It is known that the formation of mucilage in the sea is mainly caused by planktonic organisms and filamentous algae (Schiaparelli et al., 2007). Observation and follow-up of mucilage formed and lost over time is important for marine organisms and biological life (Artüz, 2002). Mucilage, also known as sea saliva, whose appearance by fishermen in the Sea of Marmara dates back to the 1990s, has been observed intensively in March-May 2021 (Tufekçi et al., 2010).

It is a very practical method to use remote sensing (RS) technology to observe possible changes in sea waters from the very beginning (Ateş et al., 2020). RS techniques are a unique method for monitoring possible changes in the world, thanks to the satellites providing 
images with different spectral, radiometric and temporal resolutions in large areas. Various classification algorithms are available for processing images and obtaining final products in RS studies. Maximum Likelihood Classification (MLC), Random Forest (RF) and Support Vector Machines (SVM) (Haque and Basak, 2017; Wang et al., 2018) for supervised classification and K-Means algorithm and Iterative Self-Organizing data analysis algorithm (ISODATA) are the most preferred algorithms for unsupervised classification (Martinez, 2003; Çelik and Gazioğlu, 2020). In addition to the classification process, various indexes are used to distinguish the target class from other classes. The Normalized Difference Vegetation Index (NDVI) (Rouse et al., 1974) is used to distinguish vegetation from other details, and the Normalized Difference Water Index (NDWI) is used to distinguish water surfaces from soil and other terrestrial surfaces (McFeeters, 1996). Especially in urban areas and shallow waters, modified NDWI (MNDWI), which uses short wave infrared SWIR band instead of near infrared NIR band, is preferred to distinguish the water surface from shaded areas $(\mathrm{Xu}$, 2006). The two separate Automatic Water Extraction Index water extraction indices have been developed, AWEI_nsh and AWEI_sh, which automatically extract water surfaces for shaded and non-shaded surfaces (Feyisa et al., 2014; Simav et al., 2015; Gazioğlu, 2018).

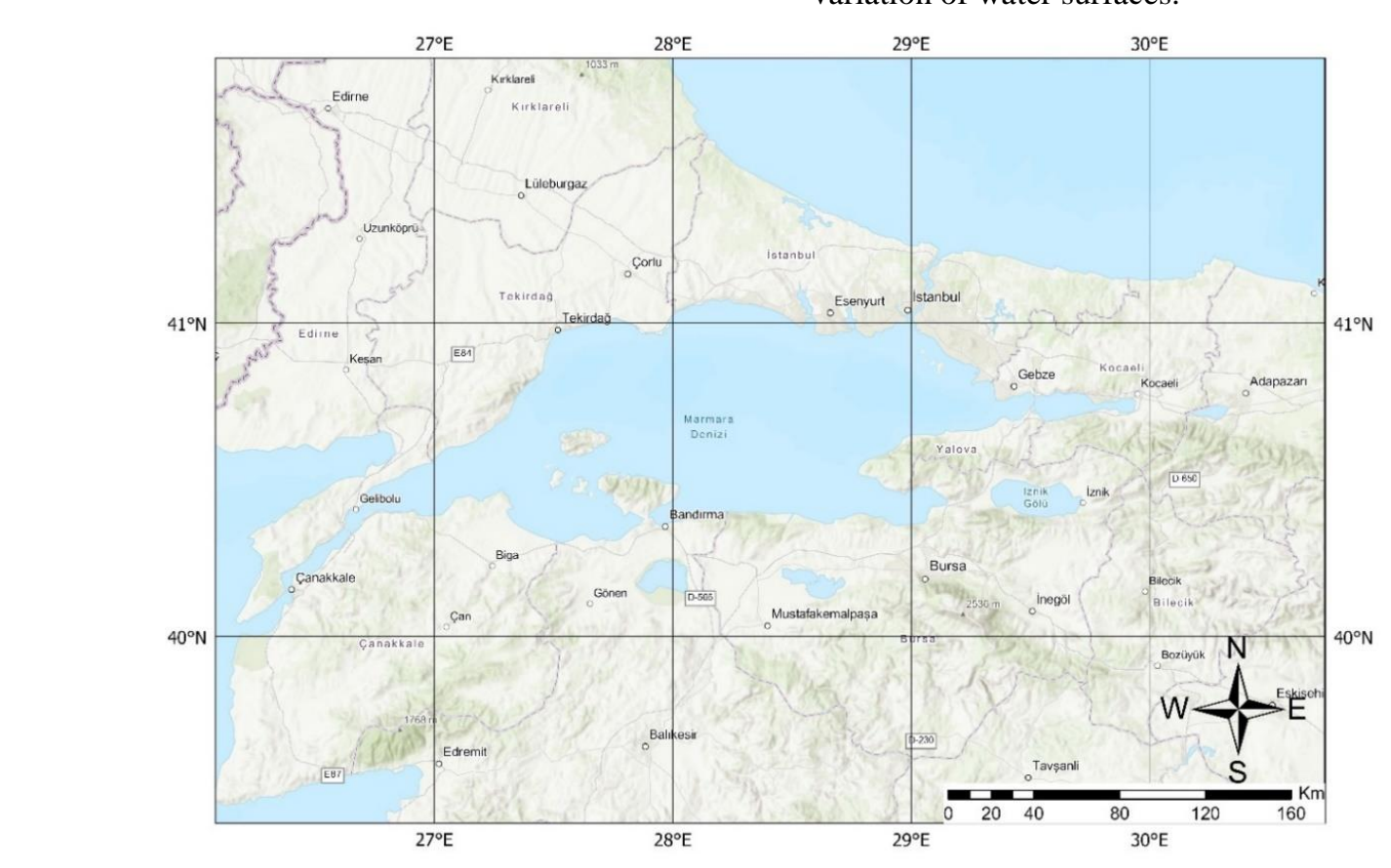

Images obtained from various satellite platforms can be used in RS studies. Sentinel constellation satellite images with Sentinel 2-A and Sentinel 2-B satellites offer 5-day temporal resolution. In addition, Sentinel satellite images provide spatial resolution ranging from $10 \mathrm{~m}$ to $60 \mathrm{~m}$ with 13 spectral bands. Observation of large areas is sometimes not possible on a single satellite image scene. For this purpose, it is possible to create a mosaic by combining multiple satellite images. Google Earth Engine (GEE) is a very useful platform for processing and analysis of created mosaic images. GEE is a RS platform that enables the use of many researchers in different fields such as global environmental observations, climate changes, drought, deforestation, agriculture, etc. It works in a cloud environment, and can process hardware-independent big data (Ülker et at., 2018; Gorelick et al., 2017). Many studies have been carried out to examine water surfaces using GEE. Pekel et al. (2016) analyzed the 32-year water dynamics from 1984 to 2015 on a global scale with GEE using more than three million Landsat images. Huang et al. (2018) used GEE to map lakes in China for determining maximum and minimum water coverage, and monitoring water surface changes. Nguyen et al. (2019) performed a fully automatic water surface extraction for $\mathrm{New}$ Zealand using AWEI values from Landsat-8 OLI images on the GEE platform. Jena et al. (2020) and Bi et al. (2020) used the GEE platform to detect seasonal variation of water surfaces.

Fig. 1. Sea of Marmara

The use of bands with different spectral properties and the use of indices obtained by algebraic processes applied to these bands in monitoring the changes in the water will distinguish the formations on the water surface from the clean water. When the literature on imaging sea mucilage, identification of it on water surfaces, determining its boundaries and coverage area is examined, it is seen that there is no study other than Zibordi and Hooker (2000) who were optically observed mucilage in the Adriatic Sea. In this study, it is aimed to determine the mucilage seen in the Marmara Sea quickly, to determine its spread and to calculate and map the area it covers on the sea. For this purpose, the formation and distribution of mucilage in the Sea of Marmara from 10.03.2021 to 06.06.2021 were examined with the JavaScript coding language on the GEE platform using RF algorithm and various indexes over Sentinel-2 images. With the help of the written code, 
mucilage formation can be detected within minutes, completely in the cloud environment, regardless of the hardware and software used. In this way, the tracking, spread, progression or reduction of the mucilage on the see surface will be determined and will guide the stakeholders and decision makers in the mucilage control work.

\section{Materials and Methods \\ Study Area}

The study area, which is surrounded by the provinces of Istanbul, Kocaeli, Bursa, Çanakkale, Tekirdağ, Yalova and Balıkesir, and the only inland sea in the world within the borders of the same country, is the Sea of Marmara. The Sea of Marmara is in a strategic location that connects the Black Sea to the Aegean and the Mediterranean, and also serves as a bridge to the European and Asian continents. The Sea of Marmara is approximately $240 \mathrm{~km}$ long, $70 \mathrm{~km}$ wide and has an area of approximately $11,870 \mathrm{~km}^{2}$ (Gazioğlu, et al., 2002).

While the surface of the Marmara Sea carries the currents from the Black Sea, the deeper waters carry the Aegean and Mediterranean currents (Artüz et al., 2007). The map of the Sea of Marmara is shown in Figure 1.

Table 1. Spectral bands and resolutions of Sentinel-2A/2B (MSI) datasets

\begin{tabular}{lccc}
\hline \multicolumn{1}{c}{ Band } & \multicolumn{3}{c}{ Sentinel - 2A/2B (MSI) } \\
\hline & Wavelength (nm) & Resolution (m) \\
B2 (Blue) & 496.6 & 492.1 & 10 \\
B3 (Green) & 560.0 & 559.0 & 10 \\
B4 (Red) & 664.5 & 665.0 & 10 \\
B8 (NIR) & 835.1 & 833.0 & 10 \\
B11 (SWIR-1) & $1,613.7$ & $1,610.4$ & 20 \\
B12 (SWIR-2) & $2,202.4$ & $2,185.7$ & 20 \\
\hline
\end{tabular}

Table 2. Classification date ranges and number of satellite images used

\begin{tabular}{lcc}
\hline Date range & Satellite Platform & Number of Images \\
\hline $10.03 .2021-30.03 .2021$ & $2 \mathrm{~A} / 2 \mathrm{~B}$ & $1 / 10$ \\
$20.03 .2021-06.04 .2021$ & $2 \mathrm{~A} / 2 \mathrm{~B}$ & $4 / 10$ \\
$10.04 .2021-05.05 .2021$ & $2 \mathrm{~A} / 2 \mathrm{~B}$ & $12 / 7$ \\
$15.04 .2021-20.05 .2021$ & $2 \mathrm{~A} / 2 \mathrm{~B}$ & $21 / 14$ \\
$17.05 .2021-06.06 .2021$ & $2 \mathrm{~A} / 2 \mathrm{~B}$ & $6 / 9$ \\
\hline
\end{tabular}

\section{Data Sources}

In this study, images from the European Space Agency (ESA) Sentinel-2A (MSI) and Sentinel-2B (MSI) constellations were used. The band information, spectral and spatial resolutions of the images used are shown in Table1.

Within the scope of the European Commission's program, the Sentinel-2A and Sentinel-2B constellations started their operations on 23 June 2015 and 7 March 2017, respectively. The satellites continue their movements in an orbit at an altitude of approximately $786 \mathrm{~km}$ from the ground. By using the two satellites together, the temporal resolution is reduced to five days. Sentinel satellite images provide 12-bit radiometric data in 13 spectral bands with spatial resolution ranging from $10 \mathrm{~m}$ to $60 \mathrm{~m}$. The satellite images used in the study are geometrically corrected images in UTM zones with WGS84 datum. Radiometrically corrected Level (L2A) images (Bottom-Of-Atmosphere (BOA) reflectance) can be obtained free of charge from Sentinels Scientific Data Hub (https://scihub.copernicus.eu/dhus/\#/home).

In the study, 5 different date ranges and a total of 94 satellite images were used. The number of images, date ranges and satellite platforms are given in Table 2 .

\section{Methods}

This study was carried out on the GEE platform, using the JavaScript coding language. In the first step of the study, satellite images were filtered according to cloud rate and date ranges (1). Then, the median values of the selected satellite images were calculated (2). Then, band indexes of NDVI, NDWI, MNDWI and AWEI_nsh were calculated (3). In the final stage, supervised classification was performed with the RF algorithm (4). The work flow diagram of the study is given in Figure 2. 


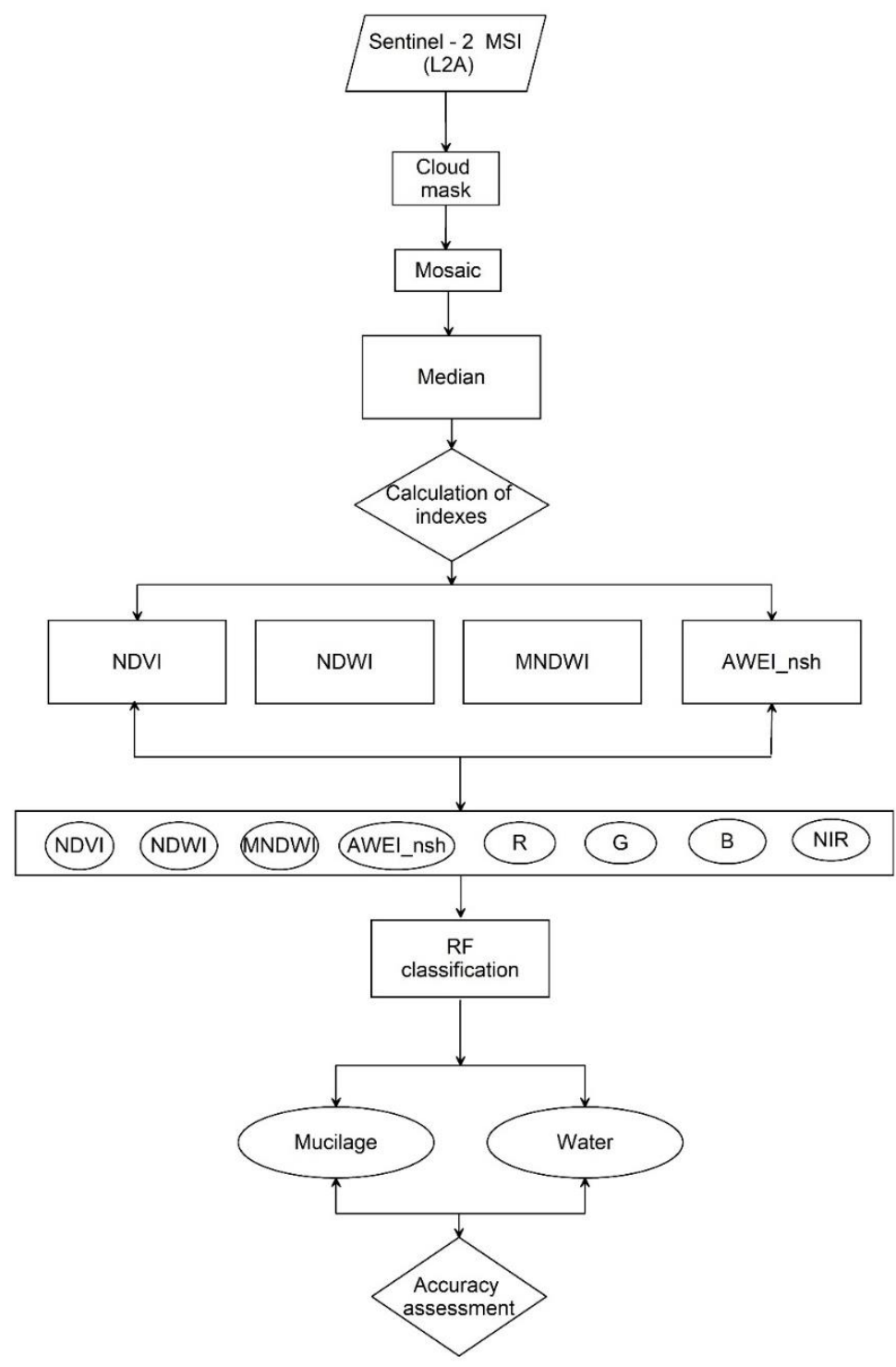

Fig. 2. Work flow diagram

Healthy plants strongly reflect near infrared and absorb most of the red light. The NDVI index was developed based on this feature of the plants by using the algebraic relationship of the NIR and RED bands. After applying NDVI index, new pixel values of the image scene range between -1 and +1 . As the value approaches +1 , the vegetation is interpreted as dense and healthy, and as it approaches -1 , the plant density is low and unhealthy (Yilmaz et al., 2021). NDWI index is designed to maximize reflectance of water by using green wavelengths, minimize the low reflectance of NIR by water features, and take advantage of the high reflectance of NIR by vegetation and soil features. As a result, water features have positive values and thus are enhanced, while other non-water details such as vegetation and soil usually have zero or negative values and therefore are suppressed (Qiao et al., 2012).

MNDWI index was designed by using SWIR band instead of NIR band in order to minimize the effect of vegetation that may occur in shallow waters as well as shadows that may occur in urban areas (Yang et al., 2018).

AWEI index has been developed to improve the classification accuracy in the areas containing shadow and dark surfaces. This index uses green, SWIR, and NIR bands and defined coefficients to increase the contrast between water and dark surfaces. In this way, two separate equations have been developed to distinguish between water and non-water pixels and to predict the water surface with high accuracy. With these two separate equations, the index used for shaded areas (AWEI_sh ) and the index used for non-shadow areas (AWEI_nsh) are calculated (Feyisa et al., 2014). In this study, due to the large water surface of the Marmara Sea, the shadow effect was ignored, so the AWEI_nsh index was used.

The indexes and formulas used in the study are given in Table 3. 
Table 3. The used Indexes and related equations

\begin{tabular}{lccc} 
Indexes & Abrivations & Equations & Referances \\
\hline $\begin{array}{l}\text { Normalized Difference } \\
\text { Vegetation Index }\end{array}$ & NDVI & $N I R-R E D$ & (Rouse et al., 1974)
\end{tabular}

\begin{tabular}{lccc} 
Normalized Difference & NDWI & $\frac{G R E E N-N I R}{G R E E N+N I R}$ & (McFeeters, 1996) \\
Water Index & MNDWI & $\frac{G R E E N-S W I R 1}{G R E E N+S W I R 1}$ & (Xu, 2006) \\
$\begin{array}{l}\text { Modifed Normalized } \\
\text { Difference Water Index }\end{array}$ & AWEI_nsh & $4 x(G R E E N-S W I R 1)-(0,25 x N I R$ & (Feyisa et al., 2014) \\
$\begin{array}{l}\text { Automated Water } \\
\text { Extraction Index }\end{array}$ & & $+2,75 x S W I R 2)$ & \\
\hline
\end{tabular}

The RF algorithm used in the study makes predictions based on decision trees. According to the sample datasets, individual decision trees come together to form decision forests. In the RF algorithm, decision forests try to find the best classification result by iterating (Breiman, 2001).

In decision trees; $\mathrm{j}$, tree estimation, is calculated by Equation (1) (Biau and Scornet, 2016).

$$
m_{n}\left(x ; \Theta_{j}, \mathrm{D}_{n}\right)=\sum_{i \in \mathbb{D}_{n}^{*}\left(\Theta_{j}\right)} \frac{1_{x_{i \in A_{n}\left(x ; \Theta_{j}, \mathrm{D}_{n}\right)^{Y}}}}{N_{n}\left(x ; \Theta_{j}, \mathrm{D}_{n}\right)}
$$

\section{Results}

The formation and distribution of mucilage in the Sea of Marmara were determined for five different time intervals using satellite images processed on the GEE platform. While determining the date ranges, attention was paid to ensure that the cloud ratios in the images are at most 5\% and represent the entire sea surface. Then, masking process was applied to images with $5 \%$ or less cloud ratio. All these images were stored in the GEE environment by creating an ImageCollection. In order to use the created ImageCollection for classification purposes, it is necessary to obtain a single image representing the region. For this purpose, all images are brought together by creating a mosaic. Overlapping images are also included in the combined images. To overcome this situation, the individual median values of all bands in the image are calculated and the ImageCollection is reduced to a single image.

Based on the image, three different classes representing land, water and mucilage were determined on the GEE
Where; $\mathrm{D}_{n}^{*}\left(\Theta_{j}\right)$ represents the set of data points before the trees are formed, and $A_{n}\left(x ; \Theta_{j}, \mathrm{D}_{n}\right)$ x represents the pixels. $N_{n}\left(x ; \Theta_{j}, \mathrm{D}_{n}\right), A_{n}\left(x ; \Theta_{j}, \mathrm{D}_{n}\right)$ is the number of contained points (Biau and Scornet, 2016).

Equation (2) is used to estimate forests (Biau \& Scornet, 2016).

$m_{M, n}\left(x ; \Theta_{1}, \ldots \ldots, \Theta_{M}, \mathrm{D}_{n}\right)=\frac{1}{M} \sum_{j=1}^{M} m_{n}\left(x ; \Theta_{j}, \mathrm{D}_{n}\right)$

where, $\mathrm{M}$ denotes the number of trees in the forest.

platform. In addition to the existing bands, NDVI, NDWI, MNDWI, AWEI_nsh indexes were also calculated and included in the classification to separate water from mucilage.

Histograms of the reflections of the indices and bands on water and mucilage surfaces are shown in Figure 3 and Figure 4, respectively. When the histograms for the water surface in Figure 3 are examined, it is seen that the values in B2, B3, B4 and B8 vary between $200-360 \mathrm{~nm}$, 140-300 nm, 40-200 nm, and 8-160 nm, respectively. The lowest reflectance was obtained in the B8 (NIR) band. The NDVI value of the calculated indices ranges from -0.60 to 0 , which is an expected range for water surfaces. According to the results, NDWI and MNDWI are highly correlated with close calculated reflection values. The NDWI and MNDWI values take a value between -1 and +1 . Positive values represent the water surface, while negative values represent other surfaces (McFeeters, 1996; Xu, 2006). The values of the AWEI_nsh index vary between 230 and 790 at the water surface. 
Mean : $289,149-$ Water

290 - StdDev: 17,02146 - Normal Dist

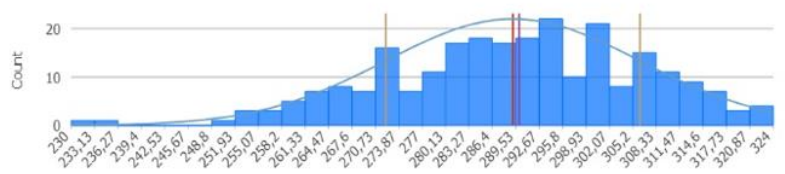

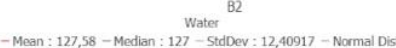

$$
\text { 与ु }
$$

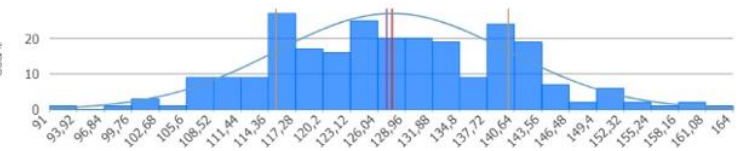

88

Water
-Mean : $-0,11676$ - Median : $-0,11639$ - Stdd Dev : 0,04196 - Normal Dist.

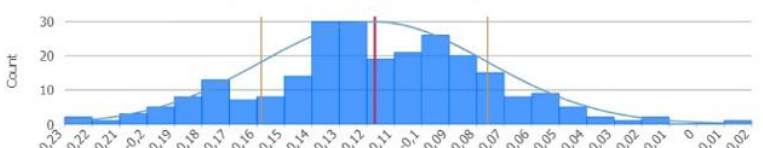

NovI

Water
-Mean : 0,46906 - Median : $0,46954-$ StdDev : 0,03324 - Normal Dist.

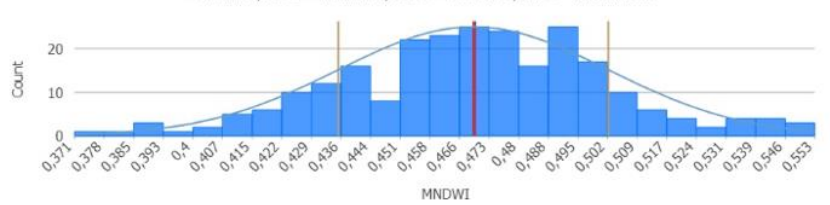

Fig. 3. Histograms of pixel values for the water surface

Musilaj

Mean : $1.247,89417$-Median : 1.120 -StdDev : 499,19426-Normal Dist.

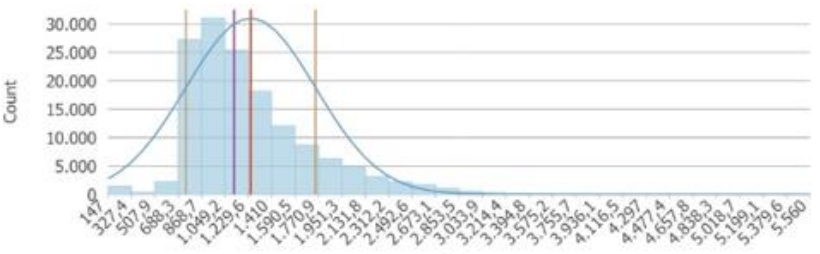

Musilaj B2

Musilaj
-Mean : $1.172,42664$-Median : 994 -StdDev : 621,1444 - Normal Dist

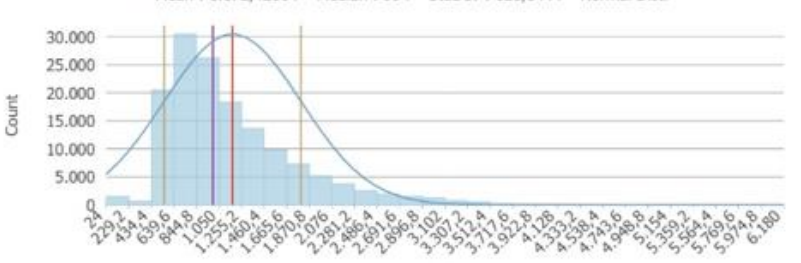

B4

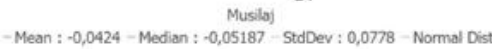

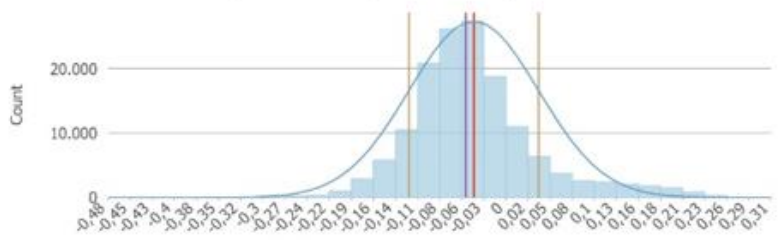

NDVI

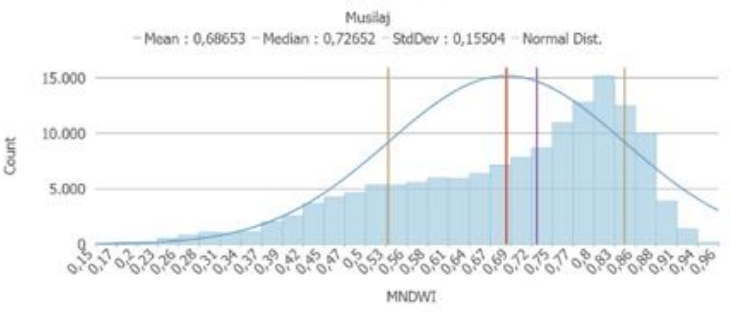

Fig. 4. Histograms of pixel values for the mucilage surface

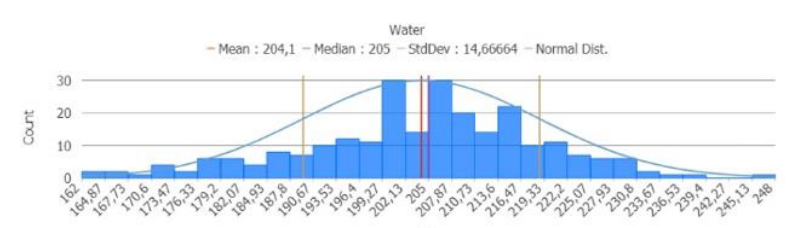

B3

Water
-Mean : $101,152-$ Median : $101-$ StdDev : 12,39546 - Normal Dist.

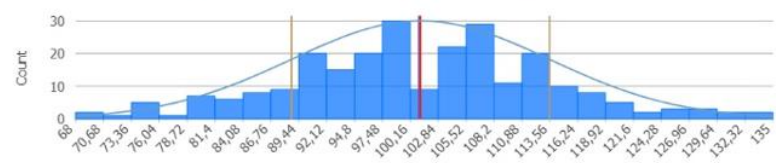

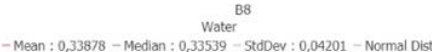

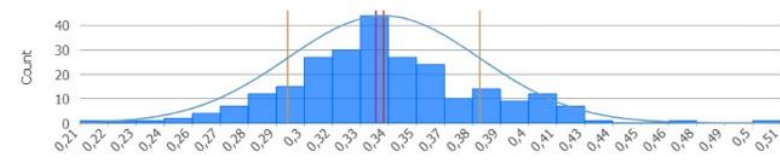

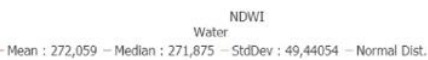

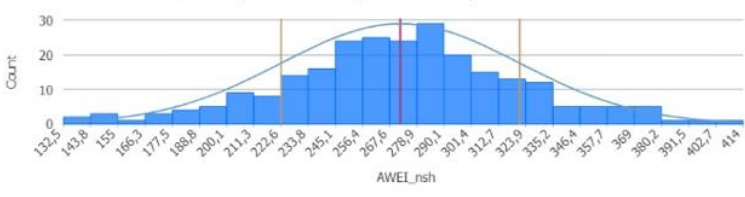

Musilaj

-Mean : 1.398,30017-Median : 1.228-StdDev : 624,40584-Normal Dist.

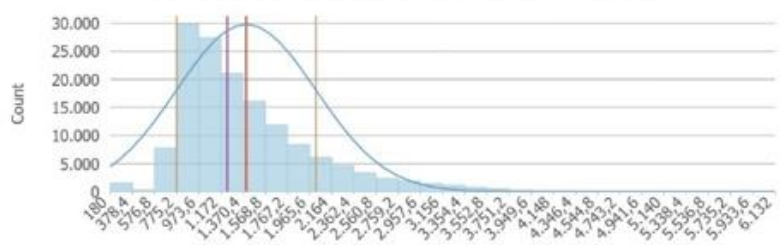

в3

Musiloj
-Meen : 1.129,14445 - Median : 890 -Stoder : 719,70619-Normal Dist.

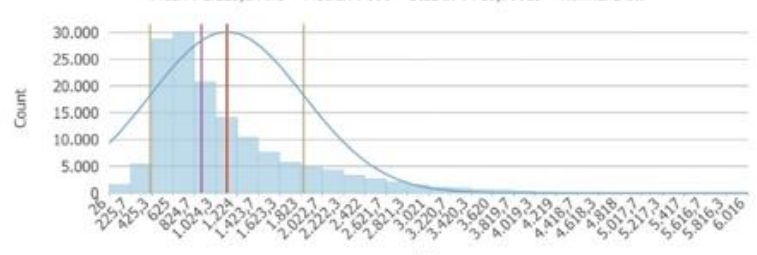

Musilaj

-Mean : 0,148-Median : 0,15468-StdDev : 0,11088-Normal Dist.

芦

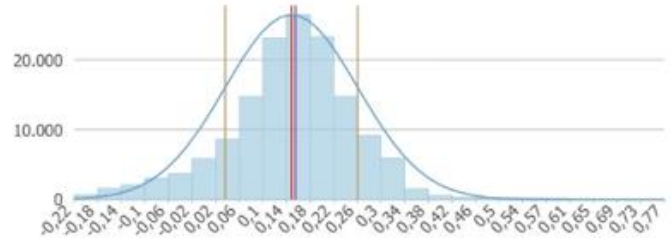

NDWI

-Mean : 3.864,71654-Median : 3.340 -StdDev : $2.386,25858$-Normal Dist.

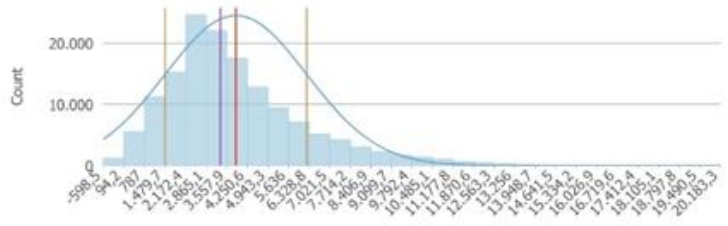

AWEI nsh 
The reflection values on the mucilage surface for $\mathrm{B} 2$, B3, B4 and B8 given in Figure 4 vary between 1402,800 nm, 180-3,300 nm, 100-3,200 nm and 20-3,300 $\mathrm{nm}$ respectively. The reflectance values of the RGB and NIR bands are close to each other and higher compared to the values obtained for water surface. The calculated NDVI values vary between -0.30 and +0.23 , NDWI values vary between -0.20 and +0.50 , MNDWI values vary between +0.23 and +0.95 and AWEI_nsh values vary between +90 and 11,200 . There is a clear difference between the index values of NDVI and AWEI_nsh for the mucilage and water surfaces.

Table 4. Classification accuracies

\begin{tabular}{ccc}
\hline Time intervals & Overall accuracy $(\%)$ & Kappa statistics $(\mathrm{K})$ \\
\hline $10.03 .2021-30.03 .2021$ & 98.39 & 0.709 \\
$20.03 .2021-06.04 .2021$ & 99.95 & 0.959 \\
$10.04 .2021-05.05 .2021$ & 99.74 & 0.986 \\
$15.04 .2021-20.05 .2021$ & 99.95 & 0.981 \\
$17.05 .2021-06.06 .2021$ & 99.71 & 0.978 \\
\hline
\end{tabular}

Kappa statistical test was applied to determine the accuracy of classifications. In the Kappa statistical test, the overall accuracy is equal to the accuracy of the entire classification. The overall accuracy value is obtained by dividing the sum of the diagonals of the classified pixels by the total number of reference pixels (Cohen, 1960). The classification accuracy values obtained are given in Table 4. The overall accuracy value was over $90 \%$. While the lowest accuracy value was $98.39 \%$, the highest value was calculated as $99.95 \%$. These high accuracy values indicate that the classification was successful and the mucilage was detected with very high precision.
The classification result maps generated using the RF algorithm on the GEE platform are shown in Figure 5a-e for five different dates. In Figure 5a, the region where mucilage is most concentrated is the Dardanelles Strait. It was seen on the classified images that there is a small amount of spread on the Anatolian coasts of the Marmara Sea. According to Figure 5b, there is no significant change in the density of mucilage in the Dardanelles, but it spreads in the Sea of Marmara, on the shores of Tekirdağ and to some extent in the Izmit Bay. In the map in Figure 5c, it is seen that mucilage spreads between the coasts of Tekirdağ and Marmara Island, around the Gemlik Bay, in the center parts of the Sea of Marmara, on the shores of Istanbul and at the entrance of the Izmit Bay. According to the map in Figure 5d, mucilage was still existing in the Dardanelles between 15.04.2021 and 20.05.2021 and intensified by moving from the Marmara Island to the central parts of the sea. In addition, it has been observed that there are spreads in the Izmit Bay, the Gemlik Bay, the shores of the Anatolian side of Istanbul and to some extent on the shores of the European side. There is also increases in mucilage cover, which appeared in small amounts on previous dates.

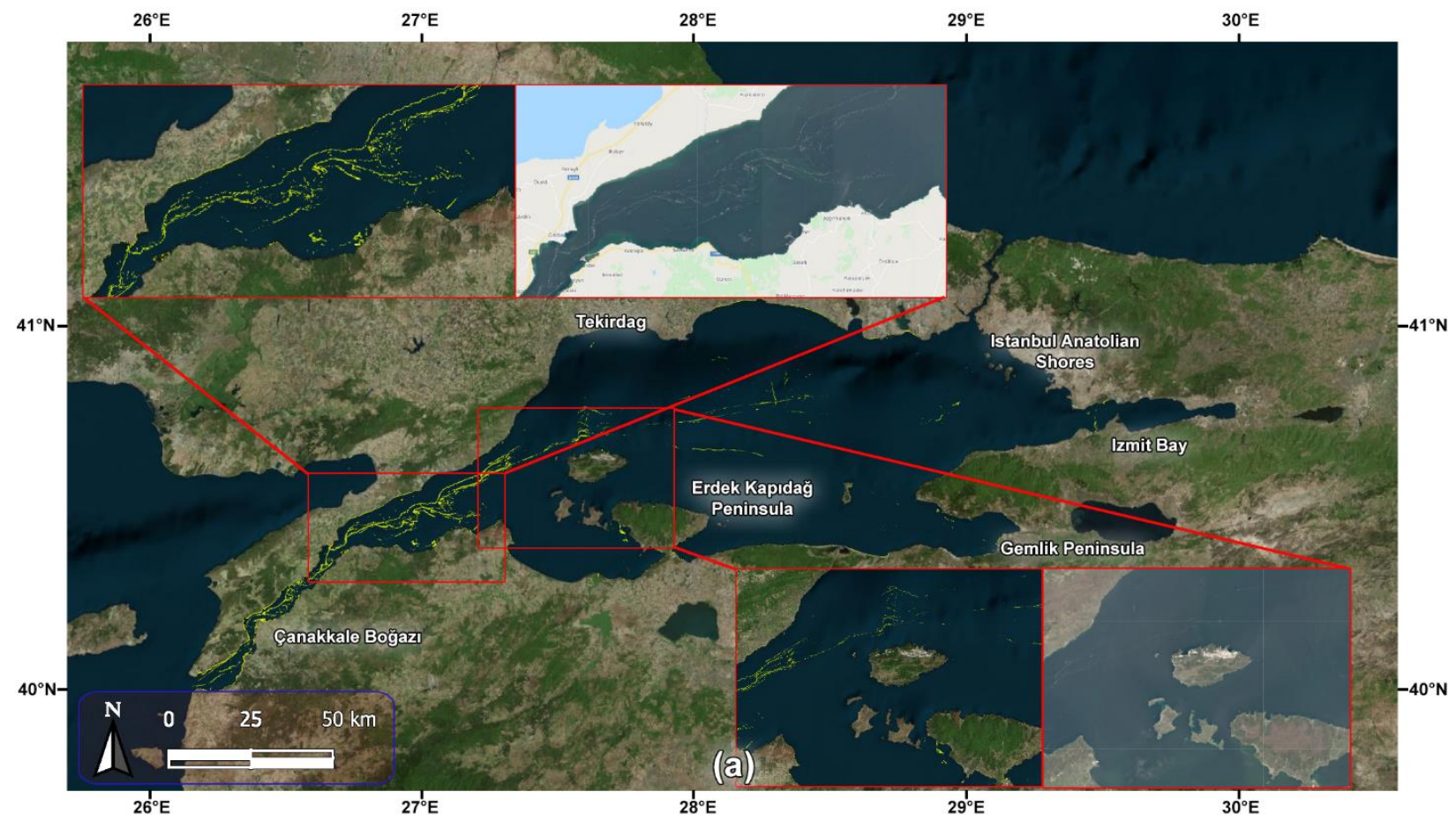




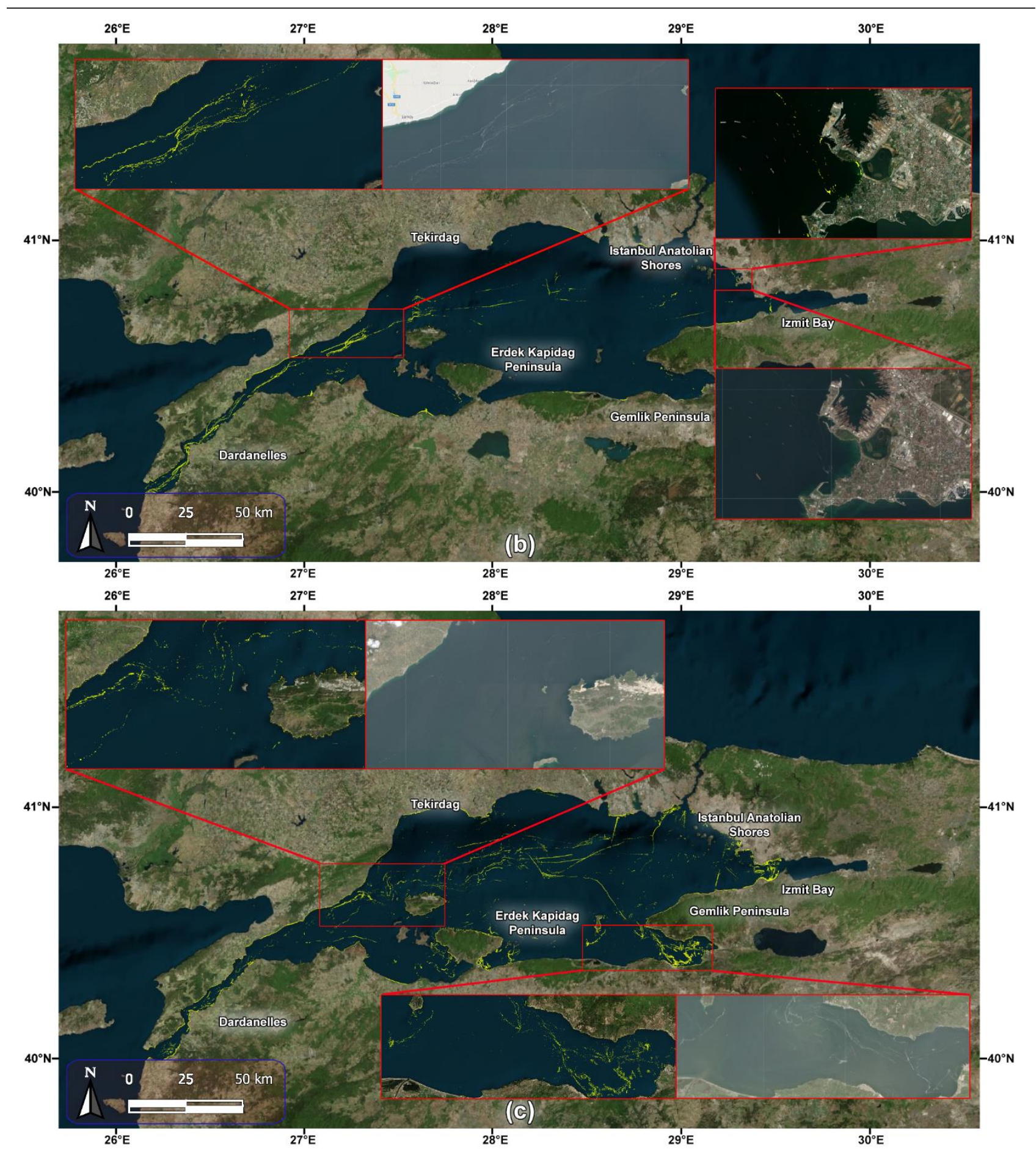




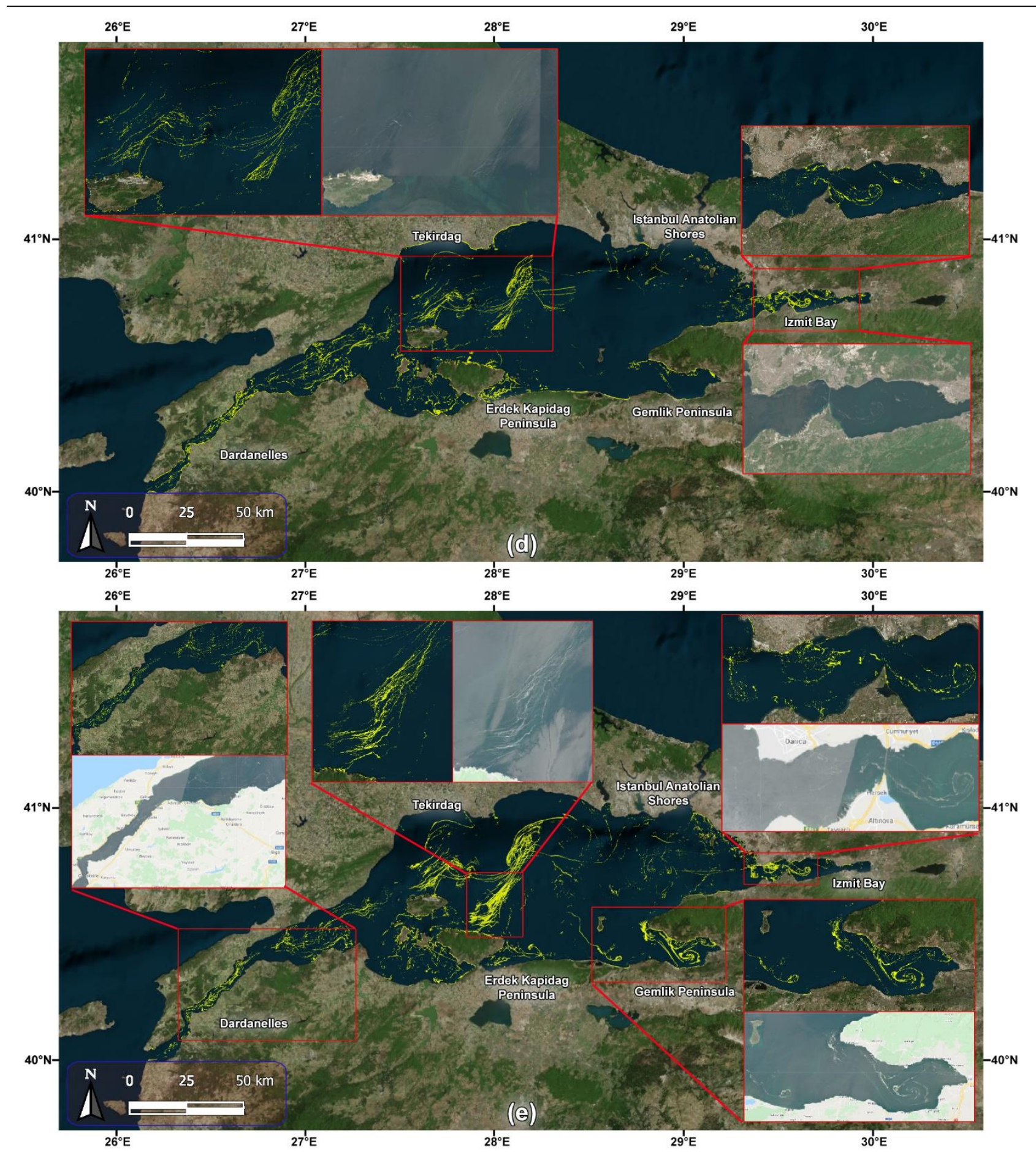

Fig. 5. a) mucilage map dated 10.03.2021-30.03.2021, b) mucilage map dated 20.03.2021-06.04.2021, c) mucilage map dated 10.04.2021-05.05.2021, d) mucilage map dated 15.04.2021-20.05.2021 map e) mucilage map dated 17.05.2021-06.06.2021

In order to determine the ratio of the area covered by the mucilage, the total surface area of the Sea of Marmara was calculated as $1,187,150$ ha by assuming the Bosporus and the Dardanelles as approximate borders. The areas covered by the mucilage in this region are given in Table 5 in chronological order. As can be seen from Table 5, the mucilage area obtained from the images from 10.03.2021 to 30.03 .2021 is $2,064.50$ ha. This value corresponds to $0.17 \%$ of the whole Marmara Sea. The mucilage covered area was calculated as 2,018.76 ha from the images gathered from 20.03.2021 to 06.04.2021, which is the second time interval. Although there is a slight decrease compared to the previous month, this difference represents a minor change due to the similarities in the spectral reflection between the classes. When the classification accuracies given in Table 5 are examined, a slight decrease in the image classification accuracy of 10.03.2021-30.03.2021 dated images, which explains that this difference is significant. The mucilage area obtained from the images dated from 10.04.2021 to 05.05.2021 increased approximately 1.5 times compared to the previous month 
as 2,960.01 ha. The mucilage covered area obtained from the images dated from 15.04.2021 to 20.05.2021 was calculated as $8,041.10$ ha. The amount of increase in this date range is about 3 times more than the previous one. Finally, the mucilage covered area obtained from the images between the dates 17.05.2021 and 06.06.2021 reached to the maximum level with a value of $12,741.94$ ha. According to the last calculations, it was determined that $1.07 \%$ of the Marmara Sea is covered with mucilage.

Table 5. Mucilage covered areas and percentages by time intervals

\begin{tabular}{ccc}
\hline Classification dates & Area (ha) & Percentage $(\%)$ \\
\hline $10.03 .2021-30.03 .2021$ & $2,064.50$ & 0.17 \\
$20.03 .2021-06.04 .2021$ & $2,018.76$ & 0.17 \\
$10.04 .2021-05.05 .2021$ & $2,960.01$ & 0.25 \\
$15.04 .2021-20.05 .2021$ & $8,041.10$ & 0.68 \\
$17.05 .2021-06.06 .2021$ & $12,741.94$ & 1.07 \\
\hline
\end{tabular}

The mucilage area variation calculated for the defined time intervals is given in Figure 6. It has been observed that the area of mucilage has grown approximately 6 times faster during the period between the first week of March and the last week of June.

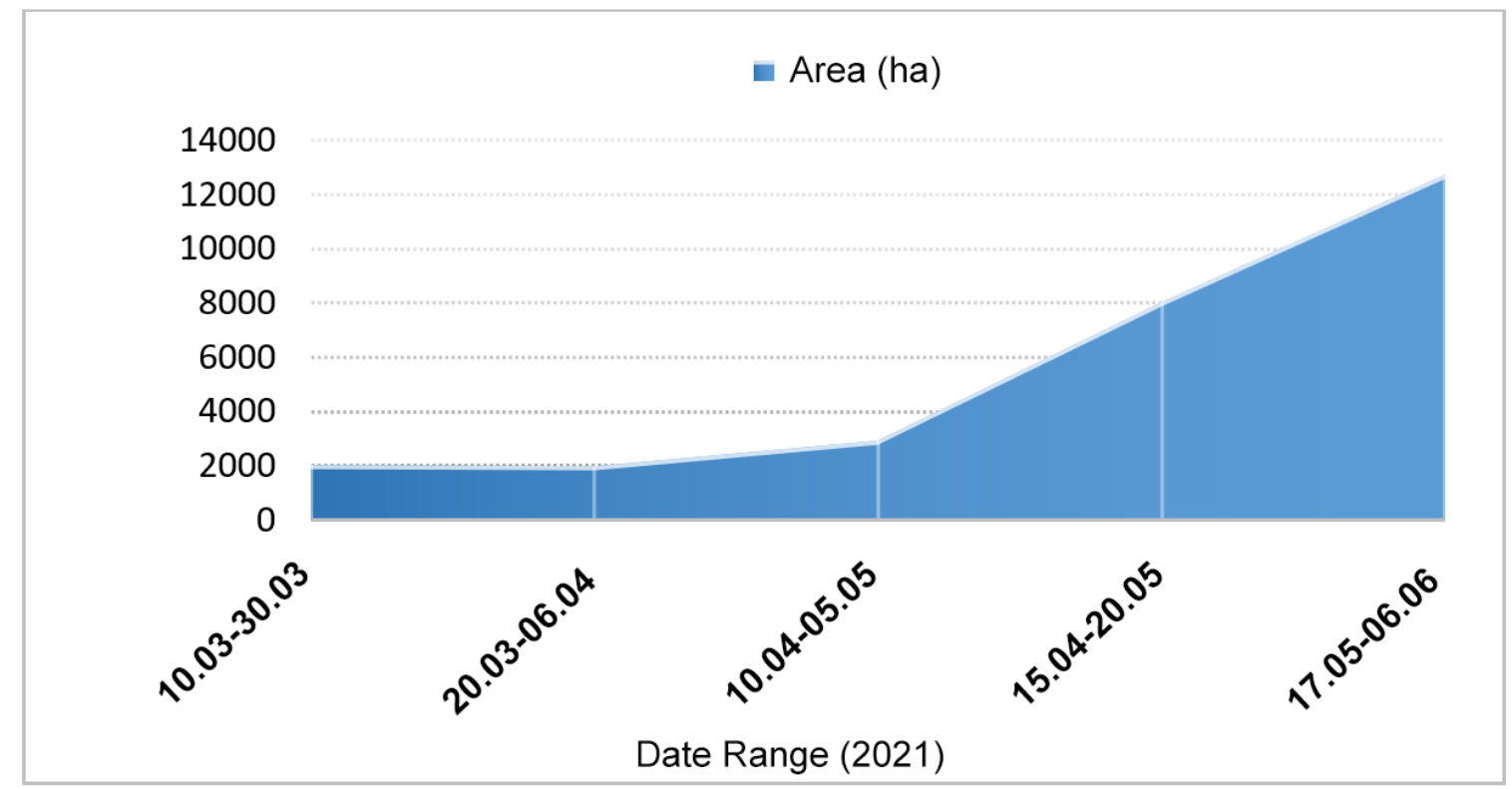

Fig. 6. Variation of mucilage formation areas

\section{Conclusion}

In this study, the distribution and spatial variation of the mucilage coverage, which started to form in the Marmara Sea since the winter months of 2021, were determined on the GEE platform with the help of satellite images for the dates from 10.03.2021 to 06.06.2021 by using UA techniques. The time intervals have been determined to cover the entire Sea of Marmara by keeping the cloud ratio to be below 5\% for each image scene. Classification studies have been carried out on a total of 94 satellite images. RGB bands, NIR band, NDVI, NDWI, MNDWI and AWEI_nsh indexes are calculated and included in the classification processes. It was observed that the reflectance values of the mucilage in these calculated band indices and in the bands used were significantly different comparing to the water surface class. These differences made it easier to distinguish the water surface from other details. Thus, the detection of target mucilage formations was easily done with RF classification techniques, which is a powerful machine learning algorithm. According to the classification results, mucilage was detected in the Dardanelles in the first images. In the following dates, it spread to the Izmit Bay and the Gemlik Bay, which are quite far from the Dardanelles. In the latest classification images, it was seen that the mucilage density increased in the Dardanelles Strait, Izmit Bay, Gemlik Bay, Erdek Kapıdağ Peninsula and the north of the Marmara Island. Between mid-May and the first week of June, it was observed that the mucilage coverage increased rapidly and the area covered by the sea surface reached $12,741.94$ ha. If no precautions are taken, it is foreseen that the biological activities will accelerate, and this increase will continue due to the increase in temperature with the effect of the summer season.

With this study, important results were obtained in the detection of mucilage on the GEE platform. With the developed methodology and written code, mucilage on the sea surface and other similar details will be detected quickly in the cloud environment, independent of software and hardware. In addition, this approach can be used not only in the Sea of Marmara, but also in any sea or ocean of the world. This study has a unique value in terms of its design for mucilage and its results. 


\section{References}

Artüz, L. M. (2002). Marmara ve Boğazların Ekolojisi ve Değişimler. B.Ü.Deniz Teknolojisi Sempozyumu, February.

Artüz, M. L., Okay, I. A., Mater, B., Artüz, O. B., Gürseler, G., Okay, N. (2007). Bilimsel Açıdan Marmara Denizi. Istanbul: Union of Turkish Bar Associations Publication.

Ateş, A. M., Yilmaz, O. S., Gülgen, F. (2020). Using remote sensing to calculate fl oating photovoltaic technical potential of a dam 's surface. Sustainable Energy Technologies and Assessments, 41(July), 100799. doi.10.1016/j.seta.2020.100799.

Balkis-Ozdelice, N., Durmuş, T., Balcı, M. (2021). A Preliminary Study on the Intense Pelagic and Benthic Mucilage Phenomenon Observed in the Sea of Marmara. International Journal of Environment and Geoinformatics, 8(4), 414-422. doi.10.30897/ijegeo.954787.

Besiktepe S, Sur HI, Özsoy E, Latif MA, Oğuz T, Ünlüata Ü (1994) The circulation and hydrography of the Marmara Sea. Prog Oceanogr 34:285-334

Bi, L., Fu, B. L., Lou, P. Q., Tang, T. Y. (2020). Delineation water of pearl river basin using Landsat images from Google Earth Engine. International Archives of the Photogrammetry, Remote Sensing and Spatial Information Sciences - ISPRS Archives, 42(3/W10), 5-10. doi.10.5194/isprs-archives-XLII3-W10-5-2020

Biau, G., Scornet, E. (2016). A random forest guided tour. Test, 25(2), 197-227. doi.10.1007/s11749016-0481-7

Breiman, L. (2001). Random Forests. Machine Learning, 45(1), 5-32. doi.10.1023/A:1010933404324

Cohen, J. (1960). Kappa: Coefficient of concordance. Educ Psych Measurement, 20(37).

Çelik, O, Gazioğlu, C. (2020). Coastline Difference Measurement (CDM) Method. International Journal of Environment and Geoinformatics, 7(1), 1-5. doi 10.30897/ijegeo.706792

Feyisa, G. L., Meilby, H., Fensholt, R., Proud, S. R. (2014). Automated Water Extraction Index: A new technique for surface water mapping using Landsat imagery. Remote Sensing of Environment, 140, 23 35. doi.10.1016/j.rse.2013.08.029

Gazioğlu, C. (2018). Biodiversity, Coastal Protection, Promotion and Applicability Investigation of the Ocean Health Index for Turkish Seas, International Journal of Environment and Geoinformatics, 5(3), 353-367. doi. 10.30897/ijegeo.484067.

Gazioğlu, C., Gökaşan, E., Algan, O. Yücel, Z. Y., Tok, B., Doğan, E., (2002). Morphologic features of the Marmara Sea from multi-beam data, Mar. Geol., 190(1-2): 397-420.

Gorelick, N., Hancher, M., Dixon, M., Ilyushchenko, S., Thau, D., Moore, R. (2017). Google Earth Engine: Planetary-scale geospatial analysis for everyone. Remote Sensing of Environment, 202, 18-27.

Haque, M. I., Basak, R. (2017). Land cover change detection using GIS and remote sensing techniques:
A spatio-temporal study on Tanguar Haor, Sunamganj, Bangladesh. Egyptian Journal of Remote Sensing and Space Science, 20(2), 251263. doi.10.1016/j.ejrs.2016.12.003

Huang, W., DeVries, B., Huang, C., Lang, M. W., Jones, J. W., Creed, I. F., Carroll, M. L. (2018). Automated extraction of surface water extent from Sentinel-1 data. Remote Sensing, 10(5), 1-18. doi.10.3390/rs10050797

Jena, R., Pradhan, B., Jung, H., Rai, A. K., Rizeei, H. M. (2020). Seasonal water change assessment at Mahanadi River, India using multi-temporal data in Google earth engine. Korean Journal of Remote Sensing, 36(1), 1-13.

Martinez, E. M. (2003). Remote Sensing Techniques for Land Use Classification of Rio Jauca Watershed Using Ikonos Images. 1-5.

McFeeters. (1996). The use of the Normalized Difference Water Index (NDWI) in the delineation of open water features. International Journal of Remote Sensing, 17(7), 1425-1432. doi.10.1080/01431169608948714

Nguyen, U. N. T., Pham, L. T. H., Dang, T. D. (2019). An automatic water detection approach using Landsat 8 OLI and Google Earth Engine cloud computing to map lakes and reservoirs in New Zealand. Environmental Monitoring and Assessment, 191(4), 1-12. doi.10.1007/s10661-0197355-X

Özalp, H. B. (2021). First massive mucilage event observed in deep waters of Çanakkale Strait (Dardanelles ), Turkey. J. Black Sea/Mediterranean Environment, 27(1), 49-66.

Pekel, J. F., Cottam, A., Gorelick, N., Belward, A. S. (2016). High-resolution mapping of global surface water and its long-term changes. Nature, 540(7633), 418-422. doi.10.1038/nature20584

Qiao, C., Luo, J., Sheng, Y., Shen, Z., Zhu, Z., Ming, D. (2012). An Adaptive Water Extraction Method from Remote Sensing Image Based on NDWI. Journal of the Indian Society of Remote Sensing, 40(3), 421-433. doi.10.1007/s12524-011-0162-7

Rouse, J. W., Haas, R. H., Schell, J. A., Deering, D. W. (1974). Monitoring Vegetation Systems in the Great Plains with Erts. NASA Spec, 351, 309.

Savun-Hekimoğlu, B., Gazioğlu, C. (2021). Mucilage Problem in the Semi-Enclosed Seas: Recent Outbreak in the Sea of Marmara. International Journal of Environment and Geoinformatics (IJEGEO), 8(4). doi.10.30897/ijegeo.955739

Schiaparelli, S., Castellano, M., Povero, P., Sartoni, G., Cattaneo- Vietti, R. (2007). A benthic mucilage event in North- Western Mediterranean Sea and its possible relationships with the summer 2003 European heatwave: short term effects on littoral rocky assemblages. Marine Ecology, 28(3), 341353.

Simav, Ö., Şeker, D.Z., Tanık, A. Gazioğlu, C. (2015). Determining the endangered fields of Turkish coasts with coastal vulnerability index. Journal of Map, 153: 1- 8

Tufekçi, V., Balkis, N., Polat Beken, Ç., Ediger, D., Mantıkçı, M. (2010). Phytoplankton composition 
and environmental conditions of a mucilage event in the Sea of Marmara. Turkish Journal of Biology, 34(2), 199-210. doi.10.3906/biy-0812-1

Ülker, D., Ergüven, O., Gazioğlu, C. (2018). Socioeconomic impacts in a Changing Climate: Case Study Syria. International Journal of Environment and Geoinformatics, 5(1), 84-93. doi.10.30897/ijegeo.406273

Wang, C., Jia, M., Chen, N., Wang, W. (2018). Longterm surface water dynamics analysis based on landsat imagery and the Google Earth Engine Platform: A case study in the middle Yangtze River Basin. Remote Sensing, 10(10), 1635. doi.10.3390/rs10101635

$\mathrm{Xu}, \mathrm{H}$. (2006). Modification of normalised difference water index (NDWI) to enhance open water features in remotely sensed imagery. International Journal of Remote Sensing, 27(14), 3025-3033. doi.10.1080/01431160600589179

Yang, X., Qin, Q., Grussenmeyer, P., Koehl, M. (2018). Urban surface water body detection with suppressed built-up noise based on water indices from Sentinel-2 MSI imagery. Remote Sensing of Environment, $\quad 219, \quad 259-270$. doi.10.1016/j.rse.2018.09.016

Yılmaz, O. S., Oruç, M. S., Ateş, A. M., Gülgen, F. (2021). Orman Yangın Şiddetinin Google Earth Engine ve Coğrafi Bilgi Sistemleri Kullanarak Analizi: Hatay-Belen Örneği. Journal of the Institute of Science and Technology, 11(2), 15191532. doi.10.21597/jist.817900

Zibordi, G., Hooker, S. B. (2000). Marine optical measurements of a mucilage event in the northern Adriatic Sea. 45(2), 322-327. 